\title{
STABILITY INDICATING REVERSE PHASE HIGH-PERFORMANCE LIQUID CHROMATOGRAPHIC METHOD FOR SIMULTANEOUS ESTIMATION OF LABETALOL AND ITS DEGRADATION PRODUCTS IN TABLET DOSAGE FORMS
}

\author{
ASHOK CHAKRAVARTHY V ${ }^{1 *}$, SAILAJA BBV ${ }^{1}$, PRAVEEN KUMAR A ${ }^{2}$
}

${ }^{1}$ Department of Inorganic and Analytical Chemistry, Andhra University, Vishakhapatnam - 530 003, Andhra Pradesh, India. ${ }^{2}$ Department of Chemistry, Changwon National University, Changwon 641-773, Korea. Email: mykingsenglish@gmail.com

Received: 25 June 2016, Revised and Accepted: 02 July 2016

\section{ABSTRACT}

Objective: The objective of the present work is to develop a simple, efficient, and reproducible stability indicating reverse phase high-performance liquid chromatographic method for simultaneous determination labetalol and its degradation products in tablet dosage forms.

Methods: The chromatographic separation of labetalol and its degradation products in tablets was carried out on Zorbax Eclipse Plus C-18 $(100 \times 4.6 \mathrm{~mm}, 3.5 \mu \mathrm{m})$ column using $0.1 \%$ trifluoroacetic acid (TFA) (v/v) in $1000 \mathrm{ml}$ of water and $0.1 \% \mathrm{TFA}(\mathrm{v} / \mathrm{v})$ in $1000 \mathrm{ml}$ of acetonitrile: Methanol (1:1) by linear gradient program. Flow rate was $1.0 \mathrm{~mL} \mathrm{~min}^{-1}$ with a column temperature of $35^{\circ} \mathrm{C}$, and detection wavelength was carried out at $230 \mathrm{~nm}$. Known impurity is well resolved from the main active drug within 14 minutes run time.

Results: The forced degradation studies were performed on labetalol tablets under acidic, basic, oxidation, thermal, humidity, and photolytic conditions. No degradation products were observed from the forced degradation studies, and the known impurity is well resolved from the main active drug. The method was validated in terms of specificity, linearity, limit of detection (LOD), limit of quantitation (LOQ), accuracy, precision, and robustness as per the ICH guidelines. The method was found to be linear in the range of LOQ to $120 \%$ for all the known and unknown impurities. The LOD and LOQ values of known impurity were found between 0.3593 and $0.7187 \mu \mathrm{g} \mathrm{mL}^{-1}$, and the percentage recovery values were in the range of 95.5-105.2\% at different concentration levels. Relative standard deviation for precision and intermediate precision results were found to be $<5 \%$. The correlation coefficient found for all compounds was not $<0.99$. The results obtained from the validation experiments prove that the developed method is a stability indicating method.

Conclusion: The developed method can be successfully applied for routine analysis, quality control analysis and also suitable for stability analysis of the simultaneous determination of labetalol and its degradation products in tablet dosage forms as per the regulatory requirements.

Keywords: Labetalol, Development, Validation, Reverse phase high-performance liquid chromatography.

(c) 2016 The Authors. Published by Innovare Academic Sciences Pvt Ltd. This is an open access article under the CC BY license (http://creativecommons. org/licenses/by/4. 0/) DOI: http://dx.doi.org/10.22159/ajpcr.2016.v9s2.13687

\section{INTRODUCTION}

Labetalol hydrochloride (labetalol)2-hydroxy-5-\{1-hydroxy-2-[(1methyl-3-phenylpropyl)amino]ethyl $\}$ benzamide hydrochloride is a mixed $\alpha / \beta$-adrenergic antagonist, which is used to treat high blood pressure $[1,2]$. The minimum requirement for adrenergic agents is a primary or secondary amine separated from a substituted benzene ring by one or two carbons. This configuration results in strong agonist activity. As the size of the substituent attached to the amine becomes greater, particularly with respect to a t-butyl group, then the molecule typically is found to have receptor affinity without intrinsic activity and is, therefore, an antagonist. Labetalol, with its 1-methyl-3-phenylpropyl substituted amine, is greater in size relative to a t-butyl group, and therefore, acts predominantly as an antagonist. The overall structure of labetalol is very polar. This was created by substituting the isopropyl group in the standard $\beta$-blocker structure with an aralkyl group, including a carboxamide group on the meta position, and by adding a hydroxyl group on the para position $[3,1]$. Structure of labetalol is shown in Fig. 1.

Labetalol has two chiral carbons and consequently exists as four stereoisomers [4]. Two of these isomers, the $(\mathrm{S}, \mathrm{S})$ - and $(\mathrm{R}, \mathrm{S})$-forms are inactive. The third, the $(\mathrm{S}, \mathrm{R})$-isomer, is a powerful $\alpha 1$ blocker. The fourth isomer, the $(\mathrm{R}, \mathrm{R})$-isomer which is also known as dilevalol, is a mixed nonselective $\beta$-blocker and selective $\alpha 1$ blocker [3]. Labetalol is typically given as a racemic mixture to achieve both $\alpha$ - and $\beta$-receptor blocking activity, which lowers the blood pressure [5,1]. It can be given intravenously in severe hypertensive situations or by mouth for long-term hypertension management [6]. Labetalol's dual $\alpha$ - and $\beta$-blockade has different physiological effects in short- and long-term situations. In short-term, acute situations, labetalol decreases blood pressure by decreasing systemic vascular resistance with little effect on stroke volume, heart rate, and cardiac output [7]. During long-term use, labetalol can reduce heart rate during exercise while maintaining cardiac output by an increase in stroke volume [8].

Labetalol is a dual $\alpha 1$ - and $\beta 1 / \beta 2$-adrenergic receptor blocker and competes with other catecholamines for binding to these sites [5] Its action on these receptors is potent and reversible. Labetalol is highly selective for postsynaptic $\alpha 1$-adrenergic and non-selective for $\beta$-adrenergic receptors. It is about equipotent in blocking both $\beta 1$ - and $\beta 2$-receptors [3]. Labetalol acts by blocking $\alpha$ - and $\beta$-adrenergic receptors, resulting in decreased peripheral vascular resistance without significant alteration of heart rate or cardiac output. The $\beta: \alpha$ antagonism of labetalol is approximately $3: 1[9,10]$. Labetalol hydrochloride is having a pKa value of $9.3[11,12]$. Labetalol is a white to off-white powder. Melts at about $180^{\circ} \mathrm{C}$, with decomposition. Soluble in water and alcohol; insoluble in ether and chloroform [13].

From the literature survey, it is evident that very few methods are available for the determination of labetalol and its impurities using high-performance liquid chromatography (HPLC). Jinqi et al. developed a method for the determination of content and related substances of labetalol hydrochloride by HPLC [14]. Meredith et al. developed an HPLC method for determination of labetalol in plasma by HPLC using fluorescence detection [15]. Vaishali et al. 
developed stability indicating reverse phase HPLC (RP-HPLC) method for determination of labetalol hydrochloride in pharmaceutical formulation [16]. Ganesan et al. developed a method of rapid analysis of labetalol in human plasma using liquid chromatography-tandem mass chromatography [17].

Methods are available in the United States Pharmacopeia [13] for the determination of labetalol and its related impurities in drug substance by thin layer chromatography (TLC) and determination of assay content in tablet dosage form by HPLC. Similarly, analytical method for related substances of labetalol hydrochloride drug substance is available in European pharmacopoeia [18] for related substances of labetalol hydrochloride drug substance.

As per the literature review, no method was reported for the estimation of labetalol and its degradation products in finished dosage forms using HPLC. The present work describes the simultaneous estimation of labetalol and its degradation products in tablet dosage forms using HPLC and also developed method gives a sensitive, specific, and stability indicating method for the determination of impurities of labetalol in a short run time by HPLC. Time required for the analysis, manpower, and solvent consumption for performing TLC analysis can be saved using the current HPLC method and finally supporting toward the green environment by following health safety and environment guidelines. Developed LC method was validated with respect to specificity, limit of detection (LOD), limit of quantitation (LOQ), linearity, precision, accuracy, and robustness. Forced degradation studies were carried out to verify the stability indicating nature of the LC method.

\section{EXPERIMENTAL}

Chemicals and reagents

Qualified standards (labetalol purity 99.3\%, 2-hydroxy impurity 99.4) are obtained from Spectrum Pharma research solutions and were used without any further purification. Samples of LABEBET $100 \mathrm{mg}$ tablets are purchased from local pharmacy. HPLC grade methanol (MeOH purity 99.8\%) and acetonitrile (ACN purity 99.9\%) were obtained from Rankem (Mumbai, India). Trifluoroacetic acid (TFA) (purity 99\%) was received from Acros Organics (India).

\section{Instrumentation}

The waters LC system (Milford, MA, USA) equipped with a diode array detector was used for method development and forced degradation studies. The output signal was monitored and processed using Empower software. Waters LC consists of 2695 separation module and 2996 photodiode array detector used for the validation study. Intermediate precision was carried out using waters 2695 separation module with 2487 dual wavelength detector. Photolytic chamber was used for photolytic degradation, and thermal degradation samples were kept at $50^{\circ} \mathrm{C}$ for 2 days in an oven.

\section{Chromatographic conditions}

The chromatographic separation was achieved on a Zorbax Eclipse Plus C-18 $(100 \times 4.6 \mathrm{~mm}, 3.5 \mu \mathrm{m})$ column using mobile phase-A composed of $0.1 \%$ TFA (v/v) in $1000 \mathrm{ml}$ of water and mobile phase-B composed of $0.1 \%$ TFA (v/v) in $1000 \mathrm{ml}$ of ACN: Methanol (1:1) by linear gradient program. The mobile phase-A was filtered with $0.45 \mu \mathrm{m}$ nylon filter. Gradient program used for chromatographic separation was shown in Table 1. Flow rate was set to $1.0 \mathrm{~mL} \mathrm{~min}^{-1}$ with a column temperature of $35^{\circ} \mathrm{C}$. Detection wavelength was carried out at $230 \mathrm{~nm}$. Injection volume was $10 \mu \mathrm{L}$. Water and $\mathrm{MeOH}$ in the ratio of 75:25 was used as diluent for the preparation of standards and samples.

\section{Preparation of standard and sample solutions}

\section{Standard stock solution of labetalol}

Accurately weighed and transferred $50 \mathrm{mg}$ of labetalol working standard into a $50 \mathrm{~mL}$ volumetric flask. Added about $30 \mathrm{~mL}$ of diluent and sonicated to dissolve with intermittent shaking. The resulting solution is diluted up to the mark with diluent and mixed well.

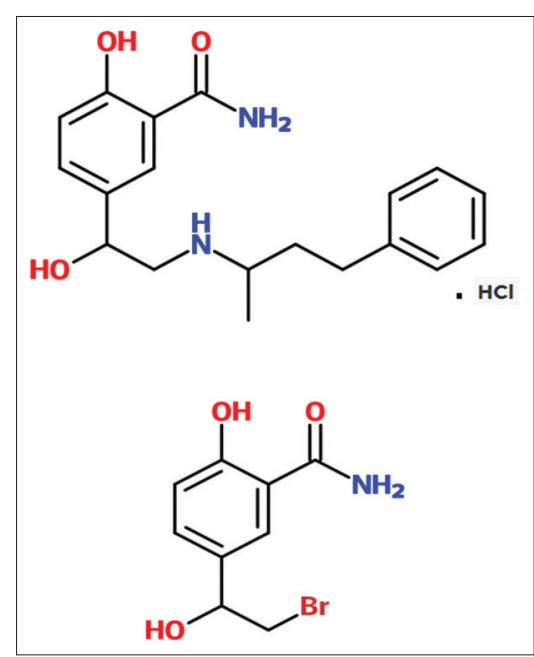

Fig. 1: Structures of labetalol hydrochloride and its related impurity 2-hydroxy impurity

Table 1: Gradient program

\begin{tabular}{lll}
\hline Time in minutes & Mobile phase-A & Mobile phase-B \\
\hline 0 & 75 & 25 \\
1 & 75 & 25 \\
10 & 20 & 80 \\
11 & 75 & 25 \\
14 & 75 & 25 \\
\hline
\end{tabular}

\section{Preparation of standard solution}

Transferred $1 \mathrm{~mL}$ of labetalol standard stock solution into a $100 \mathrm{~mL}$ volumetric flask and diluted up to the mark with the diluent and mixed well.

\section{Preparation of sample solution}

Determined the average weight of 10 tablets and transferred 10 tablets equivalent to $1000 \mathrm{mg}$ of labetalol directly into a $1000 \mathrm{~mL}$ volumetric flask. Added about $200 \mathrm{~mL}$ of diluent and sonicated for 10 minutes with intermittent shaking until tablets were completely disintegrated. Added $600 \mathrm{~mL}$ of diluent and sonicated further for 30 minutes with intermittent shaking. Made up the volume to $1000 \mathrm{~mL}$ volumetric flask with diluent and centrifuged the sample solution for 15 minutes at $3000 \mathrm{rpm}$. Transferred the resultant sample solution into HPLC vials for analysis.

\section{METHOD VALIDATION}

\section{Specificity/stress studies}

Specificity is the ability to assess unequivocally the analyte in the presence of components which may be expected to be present. Typically, these might include impurities, degradants, and matrix [19]. The specificity of the developed method was established to prove the absence of interference from placebo peaks (excipients) which is part of required pharmaceutical preparation. Degradation study was performed by subjecting the tablets to accelerated degradations such as acid, alkaline, oxidation, thermal, humidity, and photolytic conditions to evaluate the interference of degradation impurities. Thermal degradation was performed by keeping the tablets in a Petri dish and then placed them in an oven at $50^{\circ} \mathrm{C}$ for 2 days. Humidity degradation was performed by placing the tablets in a Petri dish and kept in a humidity chamber at $75 \%$ relative humidity, at $25^{\circ} \mathrm{C}$ for 2 days. Photolytic study was carried out by placing the tablets in a Petri dish in a photolytic chamber at 1.2 million lux hour's illumination and $200 \mathrm{~W} \mathrm{hrs} / \mathrm{m}^{2}$ ultraviolet energy. Acid, base, and oxidation degradations were performed by adding $3 \mathrm{~mL}$ of $1 \mathrm{~N} \mathrm{HCl}, 3 \mathrm{~mL}$ of $1 \mathrm{~N} \mathrm{NaOH}$, and $3 \mathrm{~mL}$ 
of $30 \%$ peroxide solution $\left(\mathrm{H}_{2} \mathrm{O}_{2}\right)$, respectively, to the sample solutions, and these samples are kept on bench top for $3 \mathrm{hrs}$.

\section{LOD and LOQ}

The LOD and LOQ were important for the estimation of impurities at trace levels in an analytical method. The LOD is generally quoted as the concentration yielding a signal-to-noise ratio of $2: 1$ or $3: 1$, and LOQ is quoted as the concentration yielding a signal-to-noise ratio of 10:1. The signal-to-noise ratio is determined by the following equation:

$\mathrm{s}=\mathrm{H} / \mathrm{h}$

Where, $\mathrm{H}=$ height of the peak corresponding to the component.

$\mathrm{h}=$ Absolute value of the largest noise fluctuation from the baseline of the chromatogram of a blank solution.

LOD and LOQ are also determined based on the standard deviation of the response and the slope. The detection limit expressed as " $3.3 \sigma / \mathrm{S}^{\prime}$ and quantification limit expressed as " $10 \sigma / S^{\prime}$ " where, $\sigma$ is the standard deviation of the response and $\mathrm{S}$ is the slope of the calibration curve.

\section{Linearity}

Linearity is the ability of the method to obtain results which are either directly or after mathematical transformation proportional to the concentration of the analyte within a given range. The linearity of response for labetalol and their related impurities were determined in the range from LOQ to $120 \%$. The five concentrations of each component were subjected to regression analysis by least-squares method to calculate correlation coefficient and calibration equation. The method of linear regression was used for the data evaluation.

\section{Precision}

Precision is a measure of the reproducibility of the whole analytical method under normal operating conditions. The precision was expressed as the relative standard deviation (RSD).

\section{$\% \mathrm{RSD}=($ Standard deviation/average $) \times 100$}

The precision of the developed method was carried out by 6 determinations (preparations) of the test solution by injecting the impurity spiked solution and calculated the \% RSD for impurity.

\section{Accuracy}

Accuracy or trueness was determined by applying the method to samples in which known amounts of analyte have been added. These should be analyzed against the standard and blank solutions to ensure that no interference exists. The accuracy was calculated from the test results as a percentage of the analyte recovered by the assay.

The accuracy of the present method was carried out by injecting the impurities spiked solution at three different concentration levels of LOQ $100 \%$ and $120 \%$ to their specification limit, in triplicate determinations. Percent recovery and the mean percentage recovery were calculated for known impurity.

\section{Robustness}

Robustness of the method indicates the reliability of analysis to assess the system suitability parameters under the influence of small but deliberate variations in method parameters. It was performed by injecting the impurity spiked solution by changing several parameters including different batches of the same column, flow rate, column temperature, and minor change in organic composition.

\section{Solution stability}

The impurity spiked sample solution and the standard solutions containing labetalol were prepared as per the test procedure. All these solutions were divided into two portions. One portion was stored at room temperature, and another portion was stored in the refrigerator at $2-8^{\circ} \mathrm{C}$. Freshly prepared solutions and the solutions, which were stored at room temperature and in the refrigerator $\left(2-8^{\circ} \mathrm{C}\right)$ up to 24 hrs, were injected at different time intervals. The $\%$ impurity obtained at initial was compared with the $\%$ impurity obtained at different time intervals.

\section{RESULTS AND DISCUSSION}

\section{Optimization of chromatographic conditions}

The main purpose of the current chromatographic method is to develop an LC method for the separation and quantification of known and unknown degradation products of labetalol in labetalol tablets at trace level. Labetalol and its known impurity structures were shown in Fig. 1. From the structure of labetalol, it was observed that labetalol has pKa value of 9.3. In spite of the fact that in the reversed-phase separations, $\mathrm{pH}$ of selected buffer should have the $\mathrm{pH} \pm 1.5$ units from the pKa values of the analytes [20], the selection of buffer with proper $\mathrm{pH}$ leads to ionization of analytes which consequences the sharp and symmetric peak shapes and reproducible retention times (RTs). The $\mathrm{pH}$ of the mobile phase was selected at lower side as the $\mathrm{pH}$ increases silica dissolves slowly and results in inconsistent RTs and results. $\mathrm{KH}_{2} \mathrm{PO}_{4}$ has a wide range of $\mathrm{pKa}$ values; hence, initially selected a buffer of $10 \mathrm{mM} \mathrm{KH}_{2} \mathrm{PO}_{4}$ and set the $\mathrm{pH}$ of this solution to $2.00 \pm 0.05$ using diluted orthophosphoric acid. ACN was used in the mobile phase along with Inertsil ODS 3V, C-18, $150 \times 4.6 \mathrm{~mm}, 5 \mu \mathrm{m}$ column at a column temperature of $30^{\circ} \mathrm{C}$. Flow rate was $1.0 \mathrm{~mL} /$ minute. ACN was selected as solvent for initial method development trials as it produces sharp, symmetrical peaks with less column back pressure. Gradient program used for chromatographic separation was shown in Table 2. Broad peak shape observed for labetalol peak, and also baseline humps are observed.

Next trials were performed on Hypersil BDS, C-18, $150 \times 4.6 \mathrm{~mm}$, $5 \mu \mathrm{m}$ column at a column temperature of $30^{\circ} \mathrm{C}$ using the same above chromatographic conditions with the gradient program as shown in Table 2; however, peak shapes for both labetalol and 2-hydroxyimpurity are not symmetrical, and also baseline humps are observed. Further trials were performed on Hypersil BDS, C-8, $150 \times 4.6 \mathrm{~mm}, 5 \mu \mathrm{m}$ column at a column temperature of $30^{\circ} \mathrm{C}$ using the same above chromatographic conditions except gradient program. Gradient program used for chromatographic separation was shown in Table 3. Peak fronting is observed for 2-hydroxy impurity, and baseline peaks are observed.

Hence, mobile phase changed to $0.1 \%$ of TFA (v/v) in water and ACN was used as solvent with Zorbax Eclipse Plus C-18 (100 × $4.6 \mathrm{~mm}, 3.5 \mu \mathrm{m})$ column at a column temperature of $25^{\circ} \mathrm{C}$. Gradient program used for chromatographic separation was shown in Table 4. Both labetalol and 2-hydroxy impurity peaks eluted early at 1.6 minutes, 2.9 minutes and the tailing factor is more than 2 for labetalol peak. To reduce the tailing factor, next trial was performed with $0.1 \%$ of TFA (v/v) in

Table 2: Gradient program

\begin{tabular}{lll}
\hline Time in minutes & Mobile phase-A & Mobile phase-B \\
\hline 0 & 85 & 15 \\
3 & 85 & 15 \\
20 & 30 & 70 \\
20.5 & 85 & 15 \\
25 & 85 & 15 \\
\hline
\end{tabular}

Table 3: Gradient program

\begin{tabular}{lll}
\hline Time in minutes & Mobile phase-A & Mobile phase-B \\
\hline 0 & 90 & 10 \\
3 & 90 & 10 \\
10 & 50 & 50 \\
15 & 40 & 60 \\
15.5 & 90 & 10 \\
20 & 90 & 10 \\
\hline
\end{tabular}


water as mobile phase-A and $0.2 \%$ TFA (v/v) in ACN: $\mathrm{MeOH}$ as mobile phase-B with linear gradient as mentioned in Table 5 with the same HPLC column. Although labetalol tailing is reduced in this run when compared to the previous trial, still tailing factor value is more than 2 . Further trial was taken with same chromatographic conditions except change in mobile phase-B to $0.1 \%$ TFA in ACN: $\mathrm{MeOH}$ with column temperature $35^{\circ} \mathrm{C}$ and the gradient program is as shown in Table 6 . Tailing factor for labetalol peak reduced below 2 with RTs of 2-hydroxy impurity at 2.7 minutes and labetalol at 7.1 minutes. Final trial was taken to reduce the RTs of both labetalol and 2-hydroxy impurity peaks by increasing the \% organic composition. Gradient program used is same as in Table 1. RTs of 2-hydroxy impurity, labetalol were observed at 2.5 minutes and 6.0 minutes with tailing factor values of 1.0 and 1.3 .

The screening studies were performed on a variety of columns to cover a wide range of stationary phase properties including carbon chain length, carbon loading, and surface area. Each of the selected columns was screened with different mobile phase ratios, different column temperatures, and different types of organic solvents including $\mathrm{MeOH}$ and ACN. Zorbax Eclipse Plus C-18 $(100 \times 4.6 \mathrm{~mm}, 3.5 \mu \mathrm{m})$ column was selected for the final method due to reproducible results and better peak shapes. In most of the trials, 2-hydroxy impurity of labetalol was well separated from the labetalol peak; however, baseline humps and more tailing factor for labetalol were observed. The chromatograms of blank run, $1 \%$ standard solution (concentration $-0.01 \mathrm{mg} \mathrm{mL}^{-1}$ ), control sample (concentration $-1.0 \mathrm{mg} \mathrm{mL}^{-1}$ ), and $0.15 \%$ impurity spiked samples are shown in Figs. 2-5.

The elution order of the impurity in different chromatographic conditions was 2-hydroxy impurity followed by labetalol peak in all the trials performed with different ratios of $\mathrm{ACN}, \mathrm{MeOH}$ with different buffer solutions. Elution order did not change with respect to change in chromatographic conditions and also with different brands of HPLC columns used for the trials.

\section{Selection of wavelength for labetalol and its impurity}

Spectra for known impurity and labetalol were measured from 200 to $640 \mathrm{~nm}$ for wavelength maxima. The corresponding spectrum of labetalol is shown in Fig. 6. Based on the spectra maxima, $230 \mathrm{~nm}$ was selected for identification and quantification of 2-hydroxy impurity and labetalol.

\section{Optimization of column temperature}

To study the temperature effect on resolution between the impurity peak and of labetalol peak, injected the impurity spiked solution at different column temperatures. It was observed that at a column temperature of $35^{\circ} \mathrm{C}$, known degradation impurity was well separated and also better baseline observed when compared to the other column temperatures. Although resolution between 2-hydroxy impurity peak and labetalol peak was more than 3.5 from the initial trials, better baseline was observed at a column temperature of $35^{\circ} \mathrm{C}$.

\section{METHOD VALIDATION}

The objective of validation of an analytical procedure is to demonstrate that it is suitable for its intended use. The described HPLC method has been extensively validated for its known impurity and unknown impurities as per the ICH guidelines [19]. After successful completion of method development [20-22], method validation [23-31] was performed to ensure that the developed method was capable of giving reproducible and reliable results when used by different operators employed on the same equipment of the same labor of different laboratories. Stress testing needs to be performed to elucidate the inherent stability characteristics of the active drug substance and also to prove the stability indicating the capability of the method. The developed HPLC method was validated to quantify the degradation impurities of labetalol in its tablet dosage form by determining the parameters including specificity, LOD, LOQ

Table 4: Gradient program

\begin{tabular}{lll}
\hline Time in minutes & Mobile phase-A & Mobile phase-B \\
\hline 0 & 75 & 25 \\
1 & 75 & 25 \\
10 & 20 & 80 \\
12 & 75 & 25 \\
15 & 75 & 25 \\
\hline
\end{tabular}

Table 5: Gradient program

\begin{tabular}{lll}
\hline Time in minutes & Mobile phase-A & Mobile phase-B \\
\hline 0 & 85 & 15 \\
1 & 85 & 15 \\
10 & 35 & 65 \\
12 & 85 & 15 \\
15 & 85 & 15 \\
\hline
\end{tabular}

Table 6: Gradient program

\begin{tabular}{lll}
\hline Time in minutes & Mobile phase-A & Mobile phase-B \\
\hline 0 & 83 & 17 \\
1 & 83 & 17 \\
10 & 20 & 80 \\
12 & 83 & 17 \\
15 & 83 & 17 \\
\hline
\end{tabular}

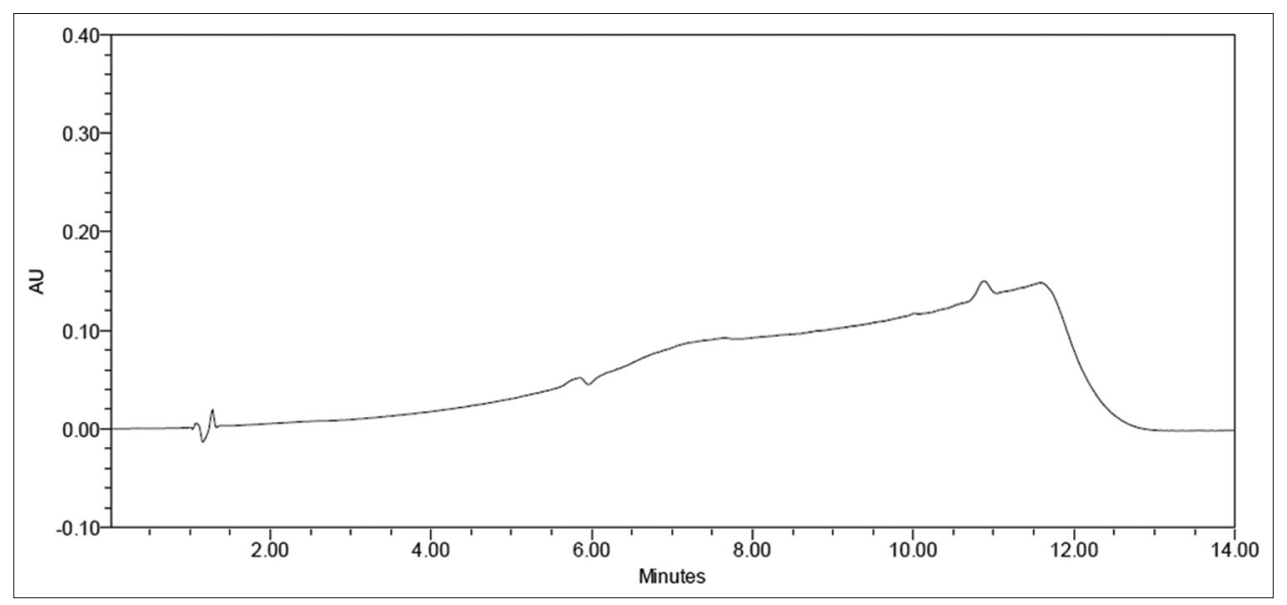

Fig. 2: Blank chromatogram 


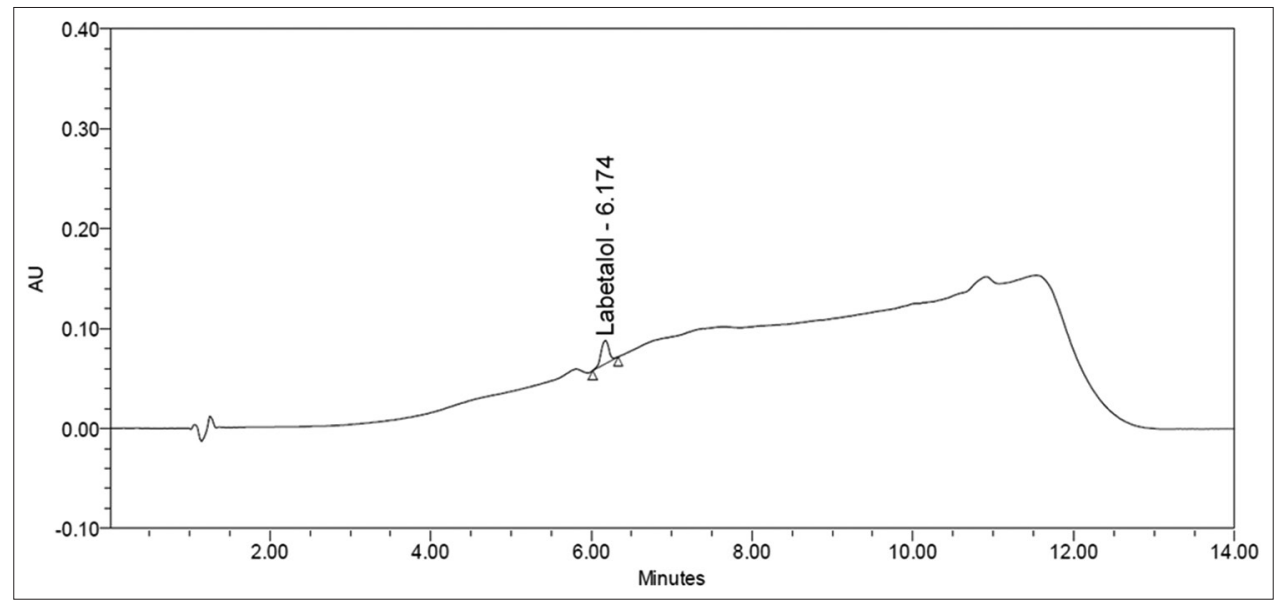

Fig. 3: Diluted standard chromatogram

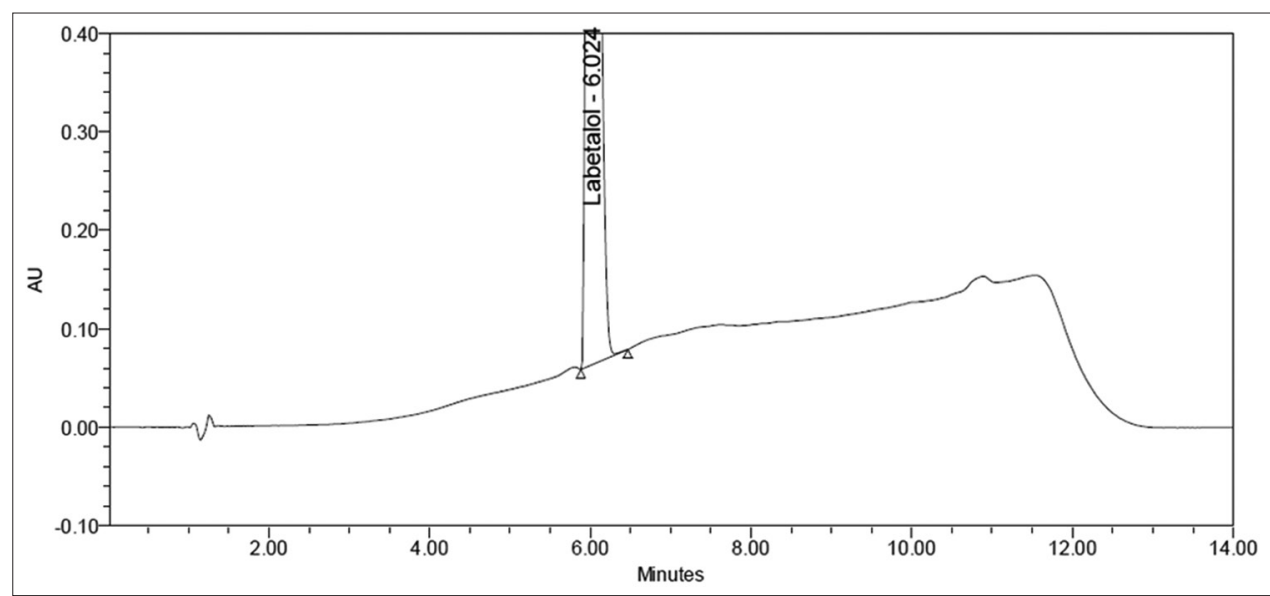

Fig. 4: Control sample chromatogram

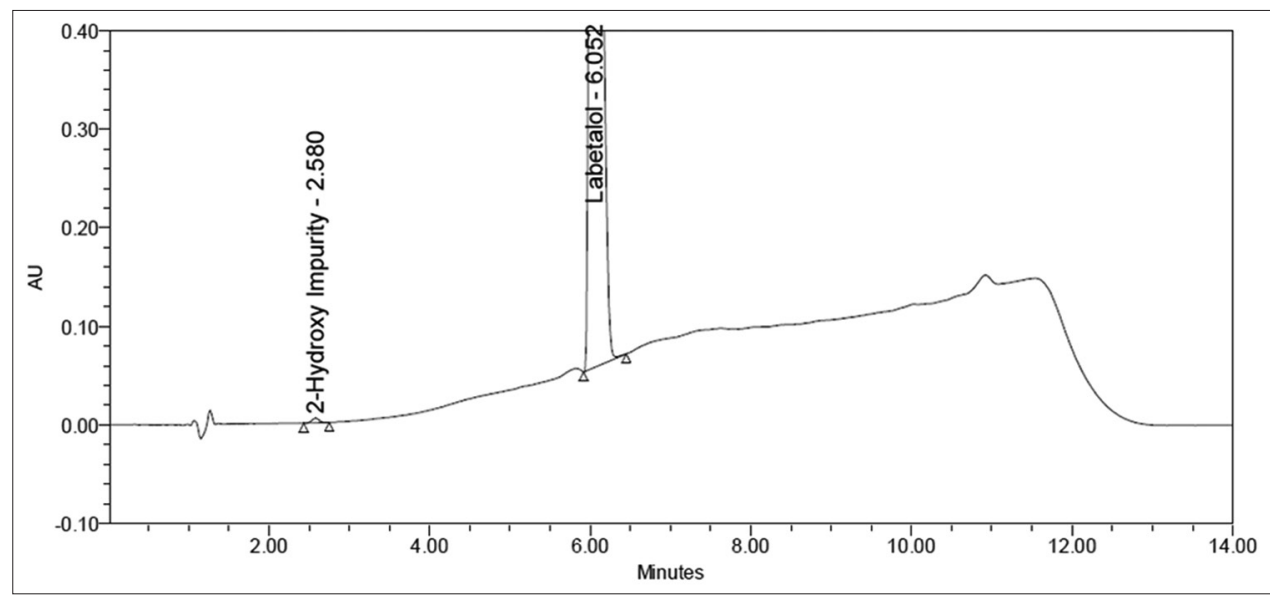

Fig. 5: Impurity spiked sample chromatogram

linearity, accuracy, precision, and robustness according to the ICH guidelines.

\section{Specificity}

Specificity of the developed method was performed by injecting the stressed degradation samples and the impurity spiked solutions. The degradation study was carried out using the samples which include tablets containing labetalol and blank solutions.
Labetalol was found to best able in all the degradation conditions. Spectral homogeneity of labetalol and its known impurity were verified. Peak purity passed for both the main active and the known impurity. Purity angle value was less than the purity threshold for all peaks indicating all peaks are spectrally homogeneous. Furthermore, spectral homogeneity of labetalol peak in degradation samples found to be similar with those obtained for the control sample, suggests that no peak was being coeluted at the RT of labetalol peak. Degradation 


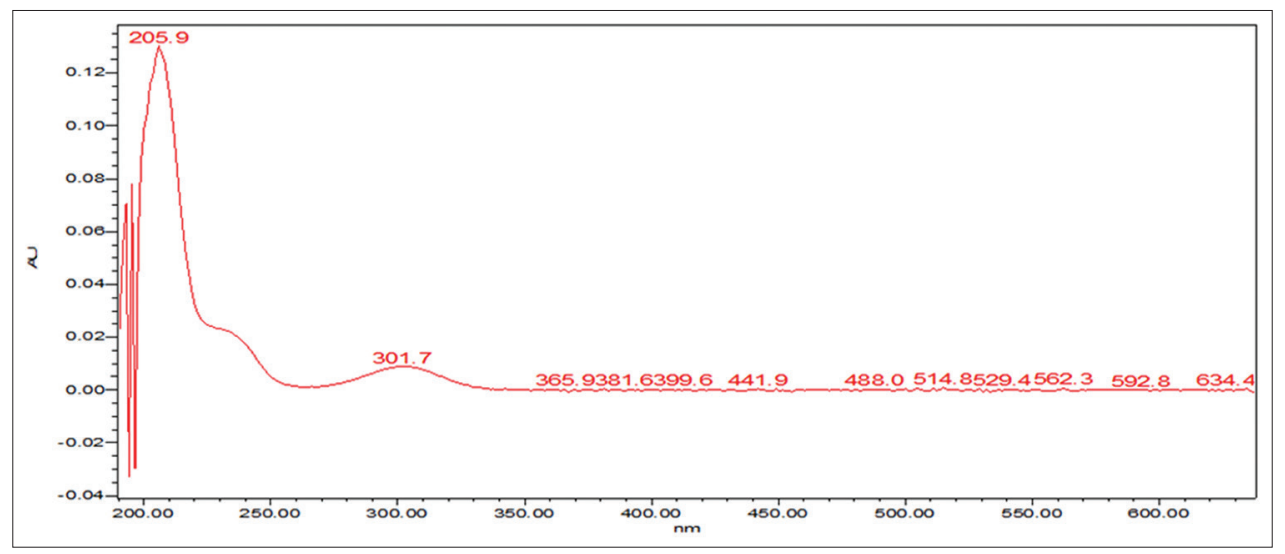

Fig. 6: Spectra of labetalol

results of labetalol in various stress conditions indicate that labetalol undergoes no degradation in the presence of respective stress conditions to for many unknown impurities.

\section{LOD and LOQ}

The LOD and LOQ were determined for labetalol and its known impurity by injecting a series of solutions with known concentrations. $\mathrm{S} / \mathrm{N}$ ratio was calculated for these solutions and selected the concentration at which level $\mathrm{S} / \mathrm{N}$ was about 3 for LOD, and the $\mathrm{S} / \mathrm{N}$ ratio was about 10 for LOQ. S/N values of LOD and LOQ for labetalol and its known impurity were shown in Table 7.

\section{Linearity}

The linearity graphs were plotted between the peak areas versus concentration to obtain the calibration curve. Linearity graphs for labetalol and its known impurity were shown in Figs. 7 and 8. The response obtained for labetalol and its known impurity was found to be linear from LOQ to $120 \%$ of standard concentration. The correlation coefficient found for all compounds was not $<0.99$. The relative response factor for 2-hydroxyimpurity was determined against its respective standard and presented in Table 7 and also statistical values of all compounds were shown in Table 7. The results demonstrate that an excellent correlation between the peak area and concentration of known impurity and labetalol.

\section{Precision}

Method precision was determined by injecting the known impurity spiked solution of six determinations and the observed values of $\%$ RSD were shown in Table 7. \% RSD for known compound in impurity spiked solution for six determinations was not more than $2.5 \%$. The intermediate precision of the method was studied by injecting the impurity spiked solution of six determinations and the values were shown in Table 7. The \% RSD difference between the two analysts is $1.7 \%$. Less difference between the two analysts shows that the developed method is precise and has good intermediate precision.

\section{Accuracy}

The percentage recovery results for known impurity of labetalol were varied from $95.5 \%$ to $105.2 \%$ at three different concentration levels, and the results were shown in Table 8 . Based on the \% recovery data, it was concluded that the developed method is capable for the estimation of its related substances and is adequate for routine analysis.

\section{Robustness}

In all the robust conditions (flow rate, column temperature, organic composition change in mobile phase and columns), the resolution between 2-hydroxy impurity and labetalol was not $<11$. Relative RT and resolution values for different robustness parameters were shown in Table 9. Furthermore, elution pattern of the known impurity and labetalol peaks remained unchanged. The peak shapes for 2-hydroxy

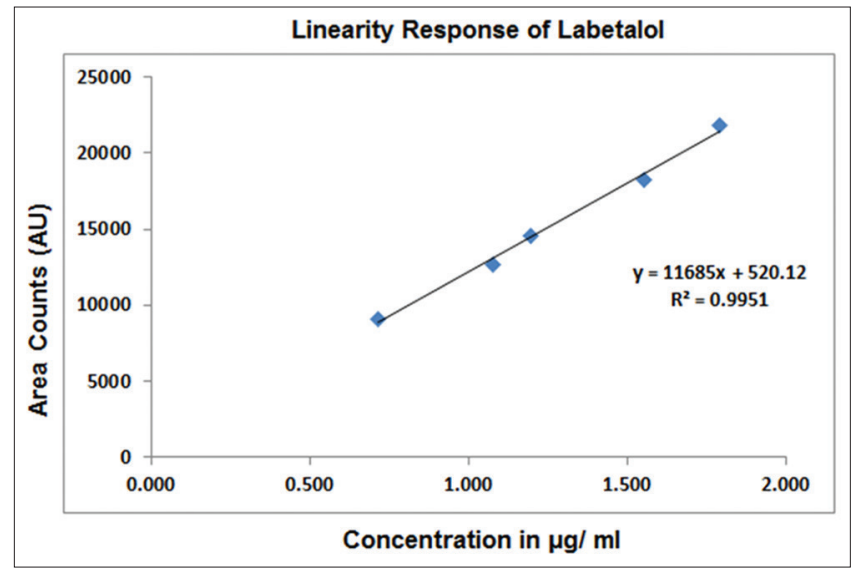

Fig. 7: Linearity graph of labetalol

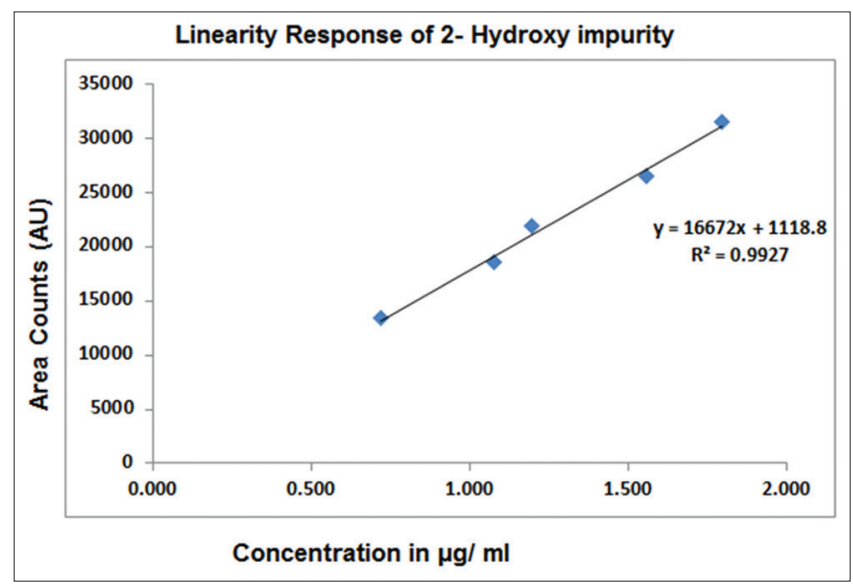

Fig. 8: Linearity graph of 2-hydroxy impurity

impurity and labetalol were found to be symmetrical. Peak purity for 2-hydroxy impurity and labetalol peaks were also tested to observe no interference in all the robust conditions.

\section{Solution stability}

The impurity percent difference was determined for solutions stored at room temperature and at refrigerated condition $\left(2-8^{\circ} \mathrm{C}\right)$ in different time intervals up to $24 \mathrm{hrs}$. 2-hydroxy impurity and labetalol peaks were found to be stable up to $24 \mathrm{hrs}$ at room temperature and also at refrigerator condition. Solution stability results at room temperature and refrigerated condition were shown in Table 10. 
Table 7: LOD, LOQ, linearity and precision data

\begin{tabular}{|c|c|c|}
\hline Parameter & Labetalol & $\begin{array}{l}\text { 2-hydroxy } \\
\text { impurity }\end{array}$ \\
\hline $\mathrm{LOD}\left(\mu \mathrm{g} \mathrm{mL}^{-1}\right)$ & 0.3583 & 0.3593 \\
\hline $\mathrm{S} / \mathrm{N}$ ratio & 12 & 16 \\
\hline $\mathrm{LOQ}\left(\mu \mathrm{g} \mathrm{mL}^{-1}\right)$ & 0.7166 & 0.7187 \\
\hline $\mathrm{S} / \mathrm{N}$ ratio & 23 & 27 \\
\hline Relative response factor & - & 0.701 \\
\hline Method precision (\% RSD) ${ }^{a}$ & - & 2.5 \\
\hline $\begin{array}{l}\text { Intermediate precision } \\
(\% \text { RSD })^{\mathrm{b}}\end{array}$ & - & 4.2 \\
\hline \multicolumn{3}{|l|}{ Regression statistics } \\
\hline Slope & $11,685.1$ & $16,671.9$ \\
\hline Intercept & 520.1 & 1118.8 \\
\hline $\begin{array}{l}\text { Coefficient of } \\
\text { determination }\left(\mathrm{R}^{2}\right)\end{array}$ & 0.9951 & 0.9927 \\
\hline $\begin{array}{l}\text { Intercept at } 95 \% \\
\text { confidence interval } \\
\text { (lower value-upper value) }\end{array}$ & $1478.5-2518.7$ & $2356.3-4593.8$ \\
\hline $\begin{array}{l}\text { Slope at } 95 \% \text { confidence } \\
\text { interval } \\
\text { (lower value-upper value) }\end{array}$ & $10,171 \cdot 2-13,198.9$ & $14,047.7-19,296.2$ \\
\hline \multicolumn{3}{|c|}{$\begin{array}{l}{ }^{a} \text { Method precision calculated from six preparations of impurity spiked } \\
\text { solutions, 'Intermediate precision calculated from six preparations of } \\
\text { impurity spiked solutions. LOQ: Limit of quantitation, LOD: Limit of detection, } \\
\text { RSD: Relative standard deviation }\end{array}$} \\
\hline \multicolumn{3}{|c|}{ Table 8: Accuracy results } \\
\hline \multirow[t]{2}{*}{$\begin{array}{l}\text { Percentage } \\
\text { impurity level }\end{array}$} & \multicolumn{2}{|c|}{$\begin{array}{l}\text { Percentage recovery range for } \\
\text { triplicate preparations }\end{array}$} \\
\hline & \multicolumn{2}{|c|}{ Percentage 2-hydroxy impurity } \\
\hline LOQ & \multicolumn{2}{|l|}{ 98.8-105.2 } \\
\hline 100 & \multicolumn{2}{|l|}{$98.4-102.3$} \\
\hline 120 & \multicolumn{2}{|l|}{$95.5-102.3$} \\
\hline
\end{tabular}

LOQ: Limit of quantitation

\section{Table 9: Robustness results}

\begin{tabular}{lll}
\hline Robustness parameters & \multicolumn{2}{l}{ 2-hydroxy impurity } \\
\cline { 2 - 3 } & RRT & Resolution \\
\hline Control sample & 0.43 & 16.5 \\
Using other batch column & 0.43 & 15.0 \\
Flow rate $(1.1 \mathrm{~mL} / \mathrm{min})$ & 0.41 & 12.8 \\
Flow rate $(0.9 \mathrm{~mL} / \mathrm{min})$ & 0.45 & 12.7 \\
Low column temperature $30^{\circ} \mathrm{C}$ & 0.43 & 19.2 \\
High column temperature $40^{\circ} \mathrm{C}$ & 0.41 & 15.7 \\
Minor component change lower & 0.41 & 12.7 \\
acetonitrile concentration at & & \\
10 min to $75 \%$ & & \\
Major component change & 0.44 & 11.8 \\
higher acetonitrile & & \\
concentration at 10 min to $85 \%$ & & \\
\hline
\end{tabular}

RRT: Relative retention time

\section{CONCLUSIONS}

A novel RP-HPLC method was developed for the separation and quantification of labetalol and its related impurities in its pharmaceutical dosage forms. Degradation behavior of labetalol was studied under various degradation conditions. No degradation peaks were observed in the respective stress conditions. 2-hydroxy impurity is well separated from the labetalol peak, and no unknown degradation impurities were observed which shows the stability indicating capability of the method. The developed method can be used for the quantification of related substances of labetalol in routine analysis.
Table 10: Solution stability results of standard and control sample at room temperature and at refrigerated condition

\begin{tabular}{llll}
\hline Solution stability & \multicolumn{2}{l}{ Time interval } & \\
\cline { 2 - 4 } & Initial & $\begin{array}{l}\text { After } \\
\mathbf{2 4} \mathbf{~ h r s}\end{array}$ & $\begin{array}{l}\text { Percentage } \\
\text { difference }\end{array}$ \\
\hline $\begin{array}{l}\text { At room temperature } \\
\text { Percentage assay of } \\
\text { standard solution }\end{array}$ & 100.6 & 99.5 & 1.1 \\
$\begin{array}{l}\text { Percentage assay of } \\
\text { sample solution }\end{array}$ & 100.2 & 99.3 & 0.9 \\
$\begin{array}{l}\text { Percentage 2-hydroxy } \\
\text { impurity }\end{array}$ & 0.154 & 0.148 & 0.01 \\
$\begin{array}{l}\text { At refrigerated condition } \\
\text { Percentage assay of } \\
\text { standard solution }\end{array}$ & 100.6 & 100.1 & 0.5 \\
$\begin{array}{l}\text { Percentage assay of } \\
\text { sample solution }\end{array}$ & 100.2 & 99.5 & 0.7 \\
$\begin{array}{l}\text { Percentage 2-hydroxy } \\
\text { impurity }\end{array}$ & 0.154 & 0.142 & 0.01 \\
\hline
\end{tabular}

\section{ACKNOWLEDGMENTS}

The authors would like to thank the Department of Inorganic and Analytical Chemistry, Andhra University, Vishakhapatnam, A.P., India, for their encouragement.

\section{REFERENCES}

1. Available from: https://www.en.wikipedia.org/wiki/Labetalol.

2. Fahed S, Grum DF, Papadimos TJ. Labetalol infusion for refractory hypertension causing severe hypotension and bradycardia: An issue of patient safety. Patient Saf Surg 2008;2:13.

3. Louis WJ, McNeill JJ, Drummer OH. Labetalol and other vasodilator/ Beta-blocking drugs. In: Handbook of Hypertension. Amsterdam, Netherlands: Elsevier Sciences Publishing Co.; 1988. p. 246-73.

4. Riva E, Mennini T, Latini R. The alpha- and beta-adrenoceptor blocking activities of labetalol and its RR-SR (50:50) stereoisomers. Br J Pharmacol 1991;104(4):823-8.

5. Robertson D, Biaggioni I. Adrenoceptor antagonist drugs. In: Katzung BG, Masters SB, Trevor AJ, editors. Basic \& Clinical Pharmacology. 12 $2^{\text {th }}$ ed. San Francisco: McGraw-Hill Lange Medical; 2012. p. 151-68.

6. Koda Kimble MA, Alldredge BK. Koda Kimble and Young's Applied Therapeutic: The Clinical Use of Drugs. Philadelphia, PA: Lippincott Williams \& Wilkins; 2013.

7. MacCarthy EP, Bloomfield SS. Labetalol: A review of its pharmacology, pharmacokinetics, clinical uses and adverse effects. Pharmacotherapy 1983;3(4):193-219.

8. Louis WJ, McNeil JJ, Drummer OH. Pharmacology of combined alphabeta-blockade. I. Drugs 1984;28 Suppl 2:16-34.

9. Bertram KG. Basic and Clinical Pharmacology. New York: McGrawHill Medical; 2006. p. 170.

10. Richards DA, Tuckman J, Prichard BN. Assessment of alpha- and beta-adrenoceptor blocking actions of labetalol. Br J Clin Pharmacol 1976;3(5):849-55.

11. Xu QA, Timothy LM. Analytical Methods for Therapeutic Drug Monitoring and Toxicology. Hoboken, NJ: John Wiley and Sons; 2011.

12. Available from: https://www.pubchem.ncbi.nlm.nih.gov/compound/ labetalol\#section $=\mathrm{Caco} 2$-Permeability.

13. The United States Pharmacopoeia. USP-37, NF-32. Rochville, MD, USA: United States Pharmacopeial Convention; 2014.

14. Jinqi Z, Lina FU, Chao L, Guogang Z. Determination of content and related substances of labetalol hydrochloride by HPLC. Chin J Modern Appl Pharm 2013;1.

15. Meredith PA, McSharry D, Elliott HL, Reid JL. The determination of labetalol in plasma by highperformance liquid chromatography using fluorescence detection. J Pharmacol Methods 1981;6(4):309-14.

16. Vaishali CK, Bhavika RC, Bavaskar SR, Barhate SD. Stability indicating RP-HPLC method for determination of labetalol hydrochloride in pharmaceutical formulation. World J Pharm Res 2015;4(4):1149-61.

17. Ganesan M, Nanjundan S, Rauthan KS, Eswaran K, Tripathi P. 
Rapid analysis of labetalol in human plasma using liquid chromatography- tandem mass chromatography. Int J Pharm Sci Res 2010;1(12):209-18.

18. European Pharmacopoeia 8.0. Labetalol Hydrochloride Monograph in European Pharmacopoeia. Reference No. 04/2013:0923; 8.0:2577-78.

19. ICH. Q2 (R1), Harmonized Tripartite Guideline, Validation of Analytical Procedures: Text and Methodology. In: Proceedings of the International Conference on Harmonization of Technical Requirements for Registration of Pharmaceuticals for Human Use; 2005.

20. Snyder LR, Kirkland JJ, Glajch JL. Handbook of Practical HPLC Method Development. $2^{\text {nd }}$ ed. Hoboken, NJ, USA: Wiley-Blackwell; 1997.

21. Basak AK, Raw AS, Al Hakim AH, Furness S, Samaan NI, Gill DS, et al. Pharmaceutical impurities: Regulatory perspective for abbreviated new drug applications. Adv Drug Deliv Rev 2007;59(1):64-72.

22. Bakshi M, Singh S. Development of validated stability-indicating assay methods - critical review. J Pharm Biomed Anal 2002;28(6):1011-40.

23. United States Food and Drug Administration. Guidance for Industry: Analytical Procedures and Methods Validation: Chemistry, Manufacturing, and Controls Documentation. Draft Guidance. Rockville, MD: USFDA; 2001.

24. Shabir GA. Validation of high-performance liquid chromatography methods for pharmaceutical analysis. Understanding the differences and similarities between validation requirements of the US Food and
Drug Administration, the US Pharmacopeia and the International Conference on Harmonization. J Chromatogr A 2003;987(1-2):57-66.

25. Center for Drug Evaluation and Research (CDER). Reviewer Guidance: Validation of Chromatographic Methods, CMC 3. USFDA; 1994

26. Guidance for Industry, Analytical Procedures and Methods Validation for Drugs and Biologics. Draft Guidance, U.S. Department of Health and Human Services, Food and Drug Admin-Istration (FDA), Center for Drug Evaluation and Research (CDER), Center for Biologics Evaluation and Research (CBER), CMC; 2014.

27. Ravichandran V, Shalini S, Sundramand KM, Rajak H. Validation of analytical methods-strategies \& importance. Int J Pharm Pharm Sci 2010;2(3):18-22.

28. Pranshu T, Singh RP, Vikash J. Validation: A critical parameter for quality control of pharmaceuticals. J Drug Deliv Ther 2012;2(3):34-40.

29. Validation of Compendial Methods. United States Pharmacopeia 37 National Formulary 32. Ch. 1225. Rockville, MD, USA: The United States Pharmacopeial Convention; 2014.

30. Ashok CV, Sailaja BB, Praveen KA. Development and validation of a dissolution method for Frovatriptan tablets by reverse phase UPLC. Int J Pharm Pharm Sci 2015;7(4):125-30.

31. Venkata RG, Pavani G, Supriya P, Madhavilatha N. Reverse phase high performance liquid chromatography method development and validation of atorvastatin in bulk drug and formulation. Asian J Pharm Clin Res 2015;8(6):84-7. 